Check for updates

Cite this: RSC Adv., 2017, 7, 56611

Received 23rd August 2017

Accepted 12th December 2017

DOI: $10.1039 / c 7 r a 09328 d$

rsc.li/rsc-advances

\section{A novel organotrophic nitrate-reducing Fe(II)- oxidizing bacterium isolated from paddy soil and draft genome sequencing indicate its metabolic versatility $\dagger$}

\author{
Min Hu,,$^{a}$ Pengcheng Chen,,$^{a b c}$ Weimin Sun, ${ }^{a}$ Fangbai Li $\mathbb{D}$ *a and Jianghu Cui ${ }^{a}$
}

The extensive application of fertilizers for growing rice results in a large input of nitrogen into paddy soils. During rice growth, iron is exposed to periodic transition under different redox conditions. Nitrate $\left(\mathrm{NO}_{3}{ }^{-}\right)$ reduction coupled to Fe(॥) oxidation (NRCFO) links the iron and nitrogen cycles. However, little is known about the biogeochemical mechanism and microorganisms involved in NRCFO in paddy soil. In the present study, we isolated an anaerobic, $\mathrm{NO}_{3}{ }^{-}$-reducing Fe(॥) oxidizer known as strain Paddy-1 from paddy soil. After 6 days of culture in $5 \mathrm{mM}$ acetate, this strain reduced $97 \%$ of $\mathrm{NO}_{3}{ }^{-}$and oxidized $86 \%$ of Fe(॥) from initial concentrations of 9.3 and $5.1 \mathrm{mM}$, respectively. A phylogenetic analysis of the $16 \mathrm{~S}$ rRNA gene sequence placed strain Paddy-1 in a clade within the order Rhodocyclales. In accordance with other NRCFO species, Fe(III) oxides produced by strain Paddy-1 were in the form of amorphous Fe(III) oxides. The reported draft genome of strain Paddy-1 predicts the presence of genes involved in denitrification, outer membrane electron transport, and iron homeostasis as well as candidate Fe(॥) oxidation genes. The physiological and genomic information on this strain provide a basis for investigating the mechanism of NRCFO in microorganisms from paddy soil.

\section{Introduction}

Iron and nitrogen are abundant elements in nature, and their redox cycling by microorganisms plays an important role in their overall biogeochemical cycles. Iron and nitrogen cycling are linked by nitrate $\left(\mathrm{NO}_{3}{ }^{-}\right)$reduction coupled to $\mathrm{Fe}(\mathrm{II})$ oxidation (NRCFO) through enzyme-mediated $\mathrm{Fe}(\mathrm{II})$ oxidation $/ \mathrm{NO}_{3}{ }^{-}$ reduction or chemical $\mathrm{Fe}(\mathrm{II})$ oxidation by $\mathrm{NO}_{2}{ }^{-}$produced during denitrification; or else by ammonium oxidation coupled to $\mathrm{Fe}(\mathrm{III})$ reduction. ${ }^{\mathbf{1 , 2}} \mathrm{NO}_{3}{ }^{-}$-dependent $\mathrm{Fe}(\mathrm{II})$ oxidation (NDFO) is the term used to describe this process. However, a valid method for differentiating abiotic (Fe(II) reacting with generated nitrite $\left[\mathrm{NO}_{2}{ }^{-}\right]$) from biotic (enzyme-mediated $\mathrm{Fe}(\mathrm{II})$ oxidation) effects in $\mathrm{Fe}(\mathrm{II})$ oxidation under $\mathrm{NO}_{3}{ }^{-}$-reducing conditions is lacking. Additionally, the Fe(II) oxidases responsible for the formation of distinct NDFO species have not been identified, casting doubt

\footnotetext{
${ }^{a}$ Guangdong Key Laboratory of Integrated Agro-environmental Pollution Control and Management, Guangdong Institute of Eco-Environmental Science \& Technology, Guangzhou 510650, P. R. China. E-mail: cefbli@soil.gd.cn; Fax: +86 20 87024123; Tel: +862037021396

${ }^{b}$ Guangzhou Institute of Geochemistry, Chinese Academy of Sciences, Guangzhou 510640, P. R. China

'Graduate University of the Chinese Academy of Sciences, Beijing 100039, P. R. China $\dagger$ Electronic supplementary information (ESI) available. See DOI: 10.1039/c7ra09328d

\$ These authors contributed equally to this work.
}

on whether this process actually occurs. ${ }^{3}$ Thus, Fe(II) oxidation could be $\mathrm{NO}_{2}{ }^{-}$-induced under anoxic conditions, whereas NRCFO accounts for the undetermined biotic or abiotic effects in such processes.

Recent studies have investigated NRCFO in sediment and hydrothermal vents as well as in deep sea and freshwater wetland environments. ${ }^{4-9}$ Long-term fertilization of paddy soils with nitrogenous manure for farming activities fosters nitrogen and iron biogeochemical cycles. ${ }^{\mathbf{1 0}} \mathrm{NO}_{3}{ }^{-}$is produced from fertilizers enriched in ammonium (ammonium sulfate or urea) in the anoxic nitrification zone (3 mm soil depth), ${ }^{11}$ in which $\mathrm{NO}_{3}{ }^{-}$replaces oxygen as the electron acceptor for $\mathrm{Fe}(\mathrm{II})$ oxidation. ${ }^{\mathbf{1 , 1 2}}$ NDFO in soil was first identified by measuring changes in the levels of nitrogen and iron species in soil depth profiles. ${ }^{\mathbf{1 0}}$ However, there is little information regarding NDFO in paddy soil ecosystems.

The availability of certain electron acceptors $\left(\mathrm{SO}_{4}{ }^{2-}, \mathrm{NO}_{3}{ }^{-}\right.$, and $\mathrm{Fe}(\mathrm{III})$ ) is a major determinant of the microbial community composition of paddy soils and sediments, ${ }^{\mathbf{1 3}}$ and could also affect the distribution and functionality of $\mathrm{Fe}(\mathrm{II})$-oxidizing bacteria (FeOB), which can in turn influence the NRCFO process in paddy soil ecosystems. Many NRCFO species have been isolated from sediment and freshwater environments including Acidovorax delafieldii 2AN, ${ }^{\mathbf{1 4}}$ Acidovorax ebreus $\mathrm{TPSY}^{\mathbf{1 5}}$ Acidovorax sp. BoFeN1, ${ }^{16}$ Azospira suillum PS (formally Dechlorosoma suillum), ${ }^{17}$ and Pseudogulbenkiania sp. $2002 .{ }^{18}$ We previously 
examined the changes in paddy soil microbial community diversity and abundance during NRCFO at circumneutral $\mathrm{pH}$ and found that Azospira, Zoogloea, and Dechloromonas species predominated during $\mathrm{NO}_{3}{ }^{-}$reduction in the presence of $\mathrm{Fe}(\mathrm{II})$ after addition of lactate. ${ }^{19}$ However, neutrophilic NRCFO species from paddy soils have not been reported, and the mechanisms underlying this process have been largely overlooked.

In the present study, we isolated Rhodocyclaceae sp. strain Paddy-1 from rice paddy soil. Strain Paddy- 1 was capable of NRCFO in the presence of acetate. The kinetics of $\mathrm{NO}_{3}{ }^{-}$ reduction and $\mathrm{Fe}(\mathrm{II})$ oxidation and mineralogy of $\mathrm{Fe}$ (III) oxides produced by this microorganism were characterized. We compared the draft genome sequence of Paddy- 1 to the genomic information of other NRCFO species. We also predicted the metabolic potential of NRCFO based on annotation of gene function. Our findings provide insight into the mechanisms of NRCFO in microorganisms from soil ecosystems.

\section{Experimental section}

\subsection{Microorganism isolation}

Anoxic paddy soil samples were collected at 10 to $20 \mathrm{~cm}$ below the soil surface with a wooden spade and preserved in $200 \mathrm{ml}$ sterilized sealed glass bottles (vaccine bottle). The paddy soil fields were located in the South China Botanical Garden of the Chinese Academy of Science in the city of Guangzhou. The geochemical properties of the paddy soil were as follows: $\mathrm{pH}$, 5.96; organic matter content, $41.0 \mathrm{~g} \mathrm{~kg}^{-1}$; total Fe, $27.9 \mathrm{~g} \mathrm{~kg}^{-1}$; dithionite/citrate/bicarbonate-extractable $\mathrm{Fe}$ concentration, $17.9 \mathrm{~g} \mathrm{~kg}^{-1}$; amorphous Fe concentration, $4.85 \mathrm{~g} \mathrm{~kg}^{-1}$; complex Fe concentration (extracted with alkaline sodium pyrophosphate at $\mathrm{pH}$ 8.5), $1.13 \mathrm{~g} \mathrm{~kg}^{-1}$; and other acid extractable elements, $\mathrm{Ca}^{2+}\left(0.965 \mathrm{~g} \mathrm{~kg}^{-1}\right), \mathrm{Mg}^{2+}\left(1.08 \mathrm{~g} \mathrm{~kg}^{-1}\right), \mathrm{K}^{+}(6.66 \mathrm{~g}$ $\left.\mathrm{kg}^{-1}\right)$, and $\mathrm{Na}^{+} 0.49 \mathrm{~g} \mathrm{~kg}^{-1}$. Subsequent procedures were carried out in a DG250 anaerobic workstation (Don Whitley Scientific, West Yorkshire Shipley, UK). $1 \mathrm{~g}$ sample of paddy soil core interval was added to $50 \mathrm{ml}$ anoxic $\left(80: 20 \mathrm{~N}_{2}: \mathrm{CO}_{2}\right.$ headspace atmosphere) $10 \mathrm{mM}$ piperazine- $N, N$-bis(2-ethanesulfonic acid) (PIPES)-buffered basal medium ( $\mathrm{pH} 7.0$ ) containing $0.2 \mathrm{ml} \mathrm{l}^{-1}$ of a micronutrient with the following composition (final concentrations, $\mathrm{mg} \mathrm{l}^{-1}$ ): $\mathrm{FeCl}_{3} \cdot 4 \mathrm{H}_{2} \mathrm{O}(2), \mathrm{CoCl}_{2} \cdot 6 \mathrm{H}_{2} \mathrm{O}(0.01), \mathrm{MnCl}_{2}$ $\cdot 4 \mathrm{H}_{2} \mathrm{O}(0.05), \mathrm{AlCl}_{3} \cdot 6 \mathrm{H}_{2} \mathrm{O}(2), \mathrm{CuCl}_{2} \cdot 2 \mathrm{H}_{2} \mathrm{O}(0.03), \mathrm{ZnCl}_{2}(0.05)$, $\mathrm{H}_{3} \mathrm{BO}_{3} \quad(0.05), \quad\left(\mathrm{NH}_{4}\right)_{6} \mathrm{Mo}_{7} \mathrm{O}_{24} \cdot 4 \mathrm{H}_{2} \mathrm{O}, \quad \mathrm{Na}_{2} \mathrm{SeO}_{3} \cdot 5 \mathrm{H}_{2} \mathrm{O} \quad(0.05)$, $\mathrm{NiCl}_{2} \cdot 6 \mathrm{H}_{2} \mathrm{O}(0.05)$, EDTA (1), and resazurin (0.2). The pH of the medium was adjusted to 7.0 using $36 \% \mathrm{HCl}$; the medium was prepared without sulfide. A vitamin mixture containing (final concentrations, $\mathrm{mg} \mathrm{l}^{-1}$ ): biotin (2), folic acid (2), pyridoxine hydrochloride (10), riboflavin (5), thiamine (5), nicotinic acid (5), pantothenic acid (5), B-12 (0.1), $p$-aminobenzoic acid (5), and thioctic acid (5) was also added to the culture $(5 \mathrm{ml}$ per liter of enrichment medium). This basal medium contained $5 \mathrm{mM}$ $\mathrm{FeCl}_{2} \cdot 4 \mathrm{H}_{2} \mathrm{O}$ and $10 \mathrm{mM} \mathrm{NaNO}$ as the electron donor and acceptor, respectively. Acetate $(5 \mathrm{mM})$ was used as an additional carbon source. After 7 days of incubation in the anaerobic workstation at $30{ }^{\circ} \mathrm{C}$, samples were transferred to fresh liquid medium (1:10 dilution) and incubated for 1 week for cell enrichment. The suspension was diluted at ratios of $1: 10$, $1: 100$, and $1: 1000$ in sterile PIPES-buffered basal medium and coated onto solid medium (prepared by mixing $2 \%$ agar with the liquid medium). The plates were then incubated in the anaerobic workstation at $30^{\circ} \mathrm{C}$ for 7 days to allow formation of heterotrophic colonies. Those showing Fe(II)-oxidizing capacity-as identified by the presence of brownish-red or brownish-green $\mathrm{Fe}(\mathrm{III})$ oxide precipitates on or around the colonies-were selected and transferred to fresh anoxic PIPESbuffered liquid medium; one isolated strain (Paddy-1) showing Fe(II)-oxidizing capacity was selected for further characterization.

\subsection{DNA extraction and 16S rRNA sequence analysis}

Late log-phase cultures of strain Paddy- 1 were grown on $5 \mathrm{mM}$ acetate and $10 \mathrm{mM} \mathrm{NO}_{3}{ }^{-}$, harvested by centrifugation $(6000 \times g$, $10 \mathrm{~min}$ ), and washed twice with $20 \mathrm{mM}$ PIPES buffer (pH 7.0). Paddy-1 genomic DNA was extracted using the EZNA Bacterial DNA kit (Omega Bio-Tek, Norcross, GA, USA), and the quality was evaluated by agarose gel electrophoresis. DNA concentration was measured using the Quant-iT dsDNA BR assay kit (Invitrogen, Inchinnan Business Park, UK) according to the manufacturer's instructions, and the sample was used as a template in PCR amplification of the 16S rRNA gene with the $27 \mathrm{~F}$ and 1492R universal primers and the following cycling program: $95{ }^{\circ} \mathrm{C}$ for $5 \mathrm{~min} ; 30$ cycles of $94{ }^{\circ} \mathrm{C}$ for $30 \mathrm{~s}, 55^{\circ} \mathrm{C}$ for $1 \mathrm{~min}$, and $72{ }^{\circ} \mathrm{C}$ for $30 \mathrm{~s}$; and $72{ }^{\circ} \mathrm{C}$ for $1.5 \mathrm{~min} .{ }^{20}$ The PCR product was purified using the DNA Gel Extraction kit (Omega Bio-Tek) and cloned into the pGEM-T vector (Promega, Madison, WI, USA), which was then transformed into Escherichia coli JM109 competent cells. Sequencing was performed on a 3730 DNA Analyzer (Applied Biosystems, Foster City, CA, USA). A BLAST search of the sequence assembled using Bioedit software $^{21}$ was performed against the National Center for Biotechnology Information (NCBI) database and the Ribosomal Database Project. ${ }^{22}$ The purity of the culture was assessed using the 16S rRNA gene clone library; 20 randomly chosen clones showed $100 \%$ sequence similarity with one another. Sequence results with a high similarity were edited, and a phylogenetic tree was constructed by the neighbor-joining method using MEGA 4.0 software. ${ }^{23}$ Identification of Paddy- 1 to the species level was performed using EzBioCloud. ${ }^{24}$

\subsection{Analysis of $\mathrm{Fe}(\mathrm{II})$ oxidation and $\mathrm{NO}_{3}{ }^{-}$reduction by strain Paddy-1}

The stoichiometry of $\mathrm{Fe}(\mathrm{II})$ oxidation and $\mathrm{NO}_{3}{ }^{-}$reduction was determined using three tubes of medium inoculated with strain Paddy- 1 at a cell density of approximately $5.5 \times 10^{6}$ cells per $\mathrm{mm}$. The cells were harvested by centrifugation at $6000 \times \mathrm{g}$ for $10 \mathrm{~min}$, washed twice with anaerobic $20 \mathrm{mM}$ PIPES buffer $(\mathrm{pH}$ 7.0), and resuspended for experiments conducted under the following conditions: (1) cells with $10 \mathrm{mM} \mathrm{NO}_{3}{ }^{-}$and $5 \mathrm{mM}$ $\mathrm{FeCl}_{2}$ representing biotic NRCFO; (2) $10 \mathrm{mM} \mathrm{NO}_{3}{ }^{-}$and $5 \mathrm{mM}$ $\mathrm{FeCl}_{2}$, an abiotic control for NRCFO; (3) cells with $5 \mathrm{mM} \mathrm{FeCl}_{2}$, a negative control for $\mathrm{Fe}(\mathrm{II})$ oxidation during cell growth; (4) cells with $10 \mathrm{mM} \mathrm{NO}_{3}{ }^{-}$, a biotic $\mathrm{NO}_{3}{ }^{-}$reduction reaction; (5) cells 
with $1 \mathrm{mM} \mathrm{NO}_{2}{ }^{-}$and $5 \mathrm{mM} \mathrm{FeCl} 2$, an abiotic reaction of $\mathrm{NO}_{2}{ }^{-}$ and $\mathrm{Fe}(\mathrm{II})$ in the presence of active cells; (6) $5 \mathrm{mM} \mathrm{NO}_{2}{ }^{-}$and $5 \mathrm{mM} \mathrm{FeCl}_{2}$, an abiotic reaction between $\mathrm{NO}_{2}{ }^{-}$and $\mathrm{Fe}(\mathrm{II})$; and (7) cells with $5 \mathrm{mM} \mathrm{NO}_{2}{ }^{-}$, a biotic $\mathrm{NO}_{2}{ }^{-}$reduction reaction. The culture conditions for evaluation of $\mathrm{NO}_{3}{ }^{-}$reduction and $\mathrm{Fe}$ (II) oxidation by strain Paddy-1 were similar to those of organism isolation, in which the strain was incubated in anoxic PIPES at $30{ }^{\circ} \mathrm{C}$ and simultaneously supplied with micronutrients and vitamins. In each treatment, $5 \mathrm{mM}$ acetate was added as a carbon substrate. After 0, 1, 2, 3, 4, and 6 days, samples were collected to examine changes in the concentrations of nitrogen and iron species during incubation. In addition, $20 \mathrm{mM}$ sodium azide $\left(\mathrm{NaN}_{3}\right)$, an inhibitor of bacterial growth, was added at the mid-late log phase of growth (2 days) in the NRCFO experiments as a control to verify that the presence of active cells was necessary for $\mathrm{Fe}(\mathrm{II})$ oxidation.

$\mathrm{NO}_{3}{ }^{-}$and $\mathrm{NO}_{2}{ }^{-}$concentrations were determined at specified time intervals by ion chromatography as previously described. ${ }^{25}$ Initial concentrations of $\mathrm{FeCl}_{2} \cdot 4 \mathrm{H}_{2} \mathrm{O}$ and $\mathrm{NaNO}_{3}$ were 5 and $10 \mathrm{mM}$, respectively. $\mathrm{N}_{2} \mathrm{O}$ in the culture headspace was quantified by gas chromatography combined with mass spectrometry. ${ }^{26}$ Ammonium concentration was determined using a $\operatorname{San}^{++}$ continuous flow analyzer (Skalar Analytical B.V., Breda, The Netherlands). For quantification of Fe(II) and Fe(III), samples were immediately transferred to $40 \mathrm{mM}$ sulfamic acid solution to prevent chemical Fe(II) oxidation. After dissolution, the concentration of $\mathrm{Fe}$ (II) in ferrozine was measured spectrophotometrically at $562 \mathrm{~nm}^{3}$ Total iron content was determined by reducing an aliquot of the sample with hydroxylamine hydrochloride prior to adding ferrozine reagent. Fe(III) concentration was calculated by subtracting the amount of $\mathrm{Fe}$ (II) from the total iron amount. All measurements in the ferrozine assay were performed in triplicate. Cell growth was monitored by detecting changes in the protein concentration with the Bradford assay using bovine serum albumin as the standard. ${ }^{27}$ Acetate was quantified by ion chromatography with conductivity detection (IonPacAS9-HC analytical column and DX-500 system; Dionex, Sunnyvale, CA, USA). To identify the organic substrates that support growth, we tested the following compounds: fumarate, sucrose, glucose, citrate, lactate, ethanol, and glycerol (5 mM each).

\subsection{Analysis of bacterial morphology and mineralogical profile}

In an anaerobic workstation, microbially produced $\mathrm{Fe}$ (III) precipitate was washed twice with anoxic phosphate-buffered saline (150 mM NaCl aqueous solution containing $0.1 \mathrm{mM}$ EDTA and $20 \mathrm{mM}$ sodium phosphate adjusted to $\mathrm{pH} 7.0$ ) to remove salts and was then dried in the same workstation. X-ray diffraction (XRD) spectra were obtained on a Scintag Pad V X-ray powder diffractometer (Scintag, Cupertino, CA, USA) using Cu$\mathrm{K} \alpha$ radiation operating at $35 \mathrm{kV}$ and $30 \mathrm{~mA}$ and a $\theta-2 \theta$ goniometer equipped with a germanium solid-state detector. Structures were identified by comparisons to spectra in the PCPDFWIN program, Joint Committee on Powder Diffraction Standards International Centre for Diffraction Data, 1997 (Newton Square, PA, USA) and to the spectra of synthetic lepidocrocite and goethite. Fe(III) precipitate was also characterized by scanning electron microscopy (SEM) coupled with energy dispersive X-ray spectroscopy (EDS) (XFlash 5010; Bruker Daltonik GmbH, Bremen, Germany). Samples were examined with a scanning electron microscope (Super 55VP; Zeiss, Oberkochen, Germany) at accelerating voltages of 15-35 kV. For transmission electron microscopy, $5 \mathrm{ml}$ of culture supernatant was centrifuged, fixed in $2.5-3 \%(\mathrm{v} / \mathrm{v})$ glutaraldehyde for $12 \mathrm{~h}$ at $4{ }^{\circ} \mathrm{C}$ and washed three times in water. Half of the samples were stained with $2 \%$ osmium tetroxide and $2 \%$ uranyl acetate, whereas the other half were left unstained. All of the specimens were dehydrated in ethanol and acetone before embedding in Epon resin. After polymerization for $24 \mathrm{~h}$ at $60^{\circ} \mathrm{C}$, sample blocks were sectioned at a thickness of $60 \mathrm{~nm}$ on a MT-X ultra microtome using a $55^{\circ}$ Diatome diamond knife; ultrathin sections were placed on 200mesh copper grids. The samples were post-stained with $2 \%$ uranyl acetate for $3 \mathrm{~min}$ prior to imaging.

\subsection{Genome sequencing of strain Paddy-1 and comparison of metabolic pathways with those reported in other $\mathrm{NO}_{3}{ }^{-}$- reducing $\mathrm{Fe}$ (II) oxidizers}

The strain Paddy-1 genome was sequenced at Macrogen (Seoul, Korea; http://www.macrogen.com) by conventional wholegenome shotgun sequencing with an Illumina HiSeq system. Two genomic libraries with an insert size of 180 and 800 bp were constructed, resulting in 139604478 reads with a read length of $101 \mathrm{bp}$ at approximately $4000 \times$ genome coverage. Quality reads were assembled using the Velvet assembler. ${ }^{28}$ The drafted genome sequence of strain Paddy-1 had 53 contigs with an N50 size of 200975 bp (length of longest contig: 506413 bp; number of contigs >1k: 38; total bases in contigs >1k: 3549457$)$. Gene identification was performed using Glimmer3 software, ${ }^{29}$ yielding 3273 genes with an average length of $960 \mathrm{bp}$. The tRNAScan-SE tool $^{30}$ was used to identify tRNA genes, whereas ribosomal RNA genes were found by searching against models of ribosomal RNA genes generated with SILVA. ${ }^{31}$ The average nucleotide identity (ANI) between the complete and draft genome sequences of all $\mathrm{NO}_{3}{ }^{-}$-reducing $\mathrm{Fe}(\mathrm{II})$ oxidizers was determined using JSpecies software with default parameters. ${ }^{32}$ The distance matrix based on obtained ANI values was used to construct a neighbor-joining tree in Splitstree. ${ }^{33}$ Protein-coding genes were predicted across genome bins using Glimmer3 (ref. 29) and functional prediction of identified open reading frames was performed by similarity searches against the Evolutionary Genealogy of Genes: Nonsupervised Orthologous Groups (eggNOG) ${ }^{34}$ and Kyoto Encyclopedia of Genes and Genomes (KEGG) ${ }^{35}$ databases using an $E$ value of $10^{-5}$. Metabolic pathways that were similar among $\mathrm{NO}_{3}{ }^{-}$reducing $\mathrm{Fe}$ (II) oxidizers were clustered based on gene abundance in eggNOG and KEGG databases after $z$-score normalization across all genomes. Proteins were also examined as potential candidates for $\mathrm{Fe}(\mathrm{II})$ oxidation by comparison to iron-oxidizing proteins in other bacteria such as Acidithiobacillus ferrooxidans ATCC23270, Leptospirillum ferrooxidans C2_3, Sideroxydans lithotrophicus ES-1, Rhodopseudomonas palustris tyrosine kinase with immunoglobulin-like and EGF-like domains (TIE)-1, and Rhodobacter ferrooxidans SW2 (Table S1†). 


\subsection{Nucleotide sequence accession number}

The 16S rRNA sequences of strain Paddy-1 were deposited in GenBank under the accession number KT322180. The draft genome sequence of strain Paddy-1 was deposited at NCBI under the BioProject ID PRJNA291117.

\section{Results}

\subsection{Enrichment and isolation of strain Paddy-1, an $\mathrm{NO}_{3}{ }^{-}$- reducing $\mathrm{Fe}(\mathrm{II})$ oxidizer}

We successfully isolated a novel, anaerobic, neutrophilic, $\mathrm{NO}_{3}{ }^{-}$reducing, $\mathrm{Fe}(\mathrm{II})$-oxidizing bacterium from paddy soil. Enrichment cultures with paddy soil were incubated for 7-10 days. The precipitates were identified as ferric iron hydroxides based on their reddish-brown color. Cells of strain Paddy-1 were Gramnegative, rod-shaped, and approximately $2-3 \mu \mathrm{m}$ in length (Fig. S1 $\dagger$ ). Phylogenetic analysis of the 16S rRNA gene sequence placed strain Paddy- 1 in the family Rhodocyclaceae and revealed that it was most closely related to Azospira oryzae 1 (GU123605) with $94 \%$ sequence similarity (Fig. S2 $\dagger$ ), followed by the NDFO A. suillum PS (AF170348, formally D. suillum PS) ${ }^{\mathbf{1 7}}$ and Pseudogulbenkiania sp. strain 2002 (AY609199) (92\% and 86\% sequence similarity, respectively). ${ }^{18}$

\section{2 $\mathrm{NO}_{3}{ }^{-}$-reducing $\mathrm{Fe}(\mathrm{II})$ oxidation by strain Paddy-1}

$\mathrm{NO}_{3}{ }^{-}$-reducing anaerobic oxidation of $\mathrm{Fe}(\mathrm{II})$ by strain Paddy-1 in the presence of acetate is shown in Fig. 1 and 2. The $\mathrm{NO}_{3}{ }^{-}$ concentration decreased by $97 \%$ over the experimental period of NRCFO from $9.28 \mathrm{mM}$ to approximately $0.28 \mathrm{mM}$ after 6 days of incubation (Fig. 1A). $\mathrm{NO}_{2}{ }^{-}$accumulation in the culture was observed on day 1 during $\mathrm{NO}_{3}{ }^{-}$-reduction coupled with $\mathrm{Fe}$ (II) oxidation. The $\mathrm{NO}_{2}{ }^{-}$concentration increase after day 6 to approximately $1.57 \mathrm{mM}$ (Fig. 1B). Stoichiometrically, the reduction of $9.28 \mathrm{mM} \mathrm{NO}_{3}{ }^{-}$should produce $9.28 \mathrm{mM} \mathrm{NO}_{2}{ }^{-}$. However, $\mathrm{NO}_{2}{ }^{-}$concentration was only $1.57 \mathrm{mM}$ on day 6 , suggesting that $\mathrm{NO}_{2}{ }^{-}$is further converted to $\mathrm{N}_{2} \mathrm{O}, \mathrm{N}_{2}$, or $\mathrm{NH}_{4}{ }^{+}$by denitrification or by reaction with $\mathrm{Fe}(\mathrm{II})$ in the medium. Ammonia concentration ranged from $0.02-0.07 \mathrm{mM}$ in the solution (Fig. 1D), and only trace quantities of $\mathrm{N}_{2} \mathrm{O}(0.03-0.2$ $\mathrm{mM}$ ) were detected in the headspace over the course of incubation (Fig. 1C), indicating that most of the $\mathrm{NO}_{3}{ }^{-}$was eventually converted to $\mathrm{N}_{2}$.

$\mathrm{Fe}(\mathrm{II})$ was oxidized concomitantly with $\mathrm{NO}_{3}{ }^{-}$reduction in the presence of acetate (Fig. 2A). During NRCFO, the Fe(II) concentration decreased by $86 \%$ from $5.1 \mathrm{mM}$ to approximately $0.7 \mathrm{mM}$ (approximately $0.73 \mathrm{mM}$ per day). In the absence of $\mathrm{NO}_{3}{ }^{-}$, there was no $\mathrm{Fe}(\mathrm{II})$ oxidation under the same conditions. In addition, no $\mathrm{Fe}(\mathrm{II})$ oxidation or $\mathrm{NO}_{3}{ }^{-}$reduction was observed during a 6 day incubation in $\mathrm{NO}_{3}{ }^{-}$and $\mathrm{Fe}(\mathrm{II})$ cultures without cells (Fig. 1 and 2). $\mathrm{NaN}_{3}(20 \mathrm{mM})$ was added at the mid-late log phases of growth (2 days) in experiments performed with cultured cells, $\mathrm{FeCl}_{2}, \mathrm{NO}_{3}{ }^{-}$, and acetate. The rate of $\mathrm{Fe}$ (II) oxidation and $\mathrm{NO}_{3}{ }^{-}$reduction was inhibited by $\mathrm{NaN}_{3}$, implying that active cells are necessary for Fe(II) oxidation (Fig. 1 and 2). Between days 1 and 6, 0.30-1.57 $\mathrm{mM} \mathrm{NO}_{2}{ }^{-}$accumulated following $\mathrm{NO}_{3}{ }^{-}$reduction in the NRCFO experiments that accelerated $\mathrm{Fe}(\mathrm{II})$ oxidation. Abiotic control experiments also showed rapid reactions between $\sim 5 \mathrm{mM} \mathrm{NO}_{2}{ }^{-}$and $\sim 5 \mathrm{mM}$ $\mathrm{FeCl}_{2}$ after 6 days (Fig. 1 and 2), suggesting that the high $\mathrm{NO}_{2}{ }^{-}$ concentration contributed to $\mathrm{Fe}(\mathrm{II})$ oxidation in cultures with strain Paddy-1. $\mathrm{N}_{2} \mathrm{O}(0.03-0.21 \mathrm{mM})$ and $\mathrm{NH}_{4}{ }^{+}(0.02-0.07 \mathrm{mM})$
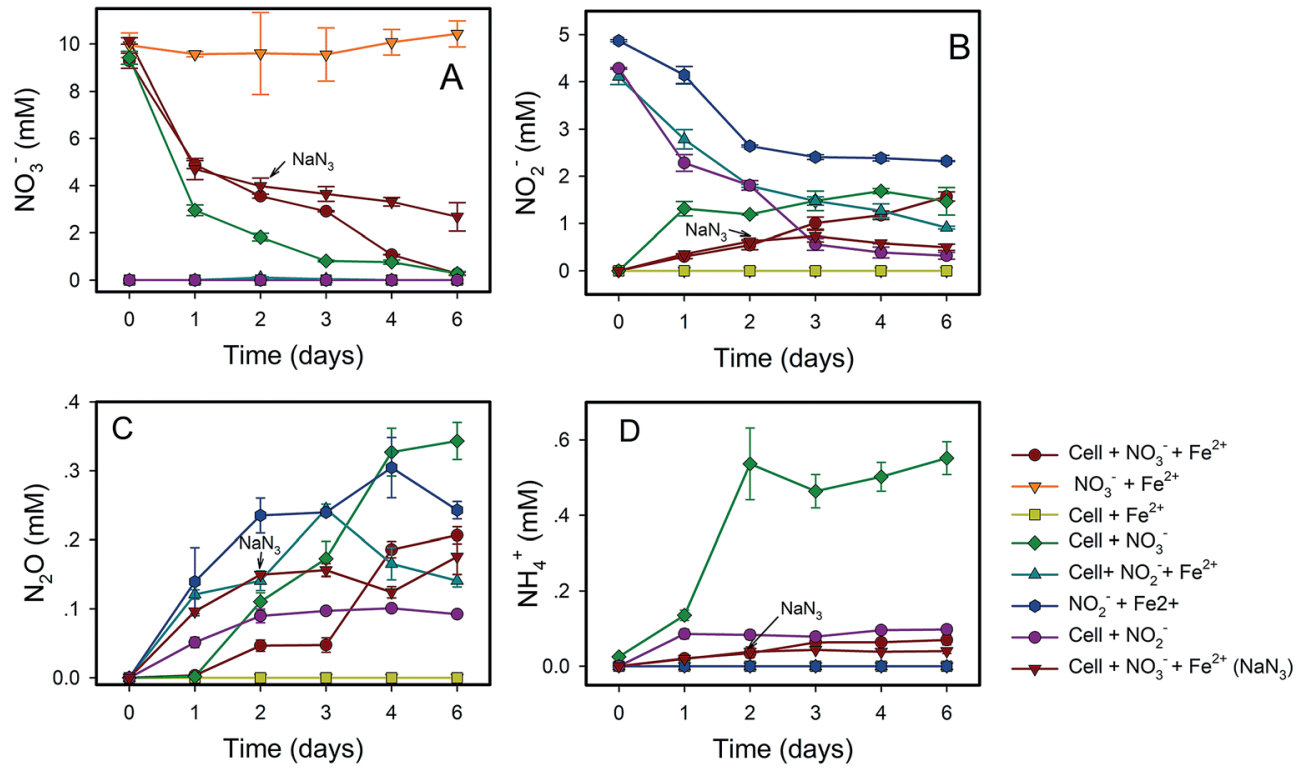

Fig. 1 Transformations of nitrate (A), nitrite (B), nitrous oxide (C) and ammonium (D) by (1) Rhodocyclaceae sp. strain Paddy-1 ( $10^{9}$ cells per ml) with $10 \mathrm{mM} \mathrm{NO}_{3}^{-}$and $5 \mathrm{mM} \mathrm{FeCl}_{2}$; (2) $10 \mathrm{mM} \mathrm{NO}_{3}{ }^{-}$and $5 \mathrm{mM} \mathrm{FeCl}_{2}$; (3) cells with $5 \mathrm{mM} \mathrm{FeCl}_{2}$; (4) cells with $10 \mathrm{mM} \mathrm{NO}_{3}^{-}$; (5) cells with 1 mM $\mathrm{NO}_{2}{ }^{-}$and $5 \mathrm{mM} \mathrm{FeCl}_{2}$; (6) $5 \mathrm{mM} \mathrm{NO}_{2}^{-}$and $5 \mathrm{mM} \mathrm{FeCl}_{2}$; (7) cells with $5 \mathrm{mM} \mathrm{NO}_{2}^{-}$; (8) $20 \mathrm{mM} \mathrm{NaN}_{3}$ was added at the mid-late log phase of growth (2 days) during the NRCFO experiments. In each treatment, $5 \mathrm{mM}$ acetate was added as a carbon substrate. Data were all presented as means \pm standard deviations (SD) of triplicate. When not shown, error bars are smaller than the symbol size. 

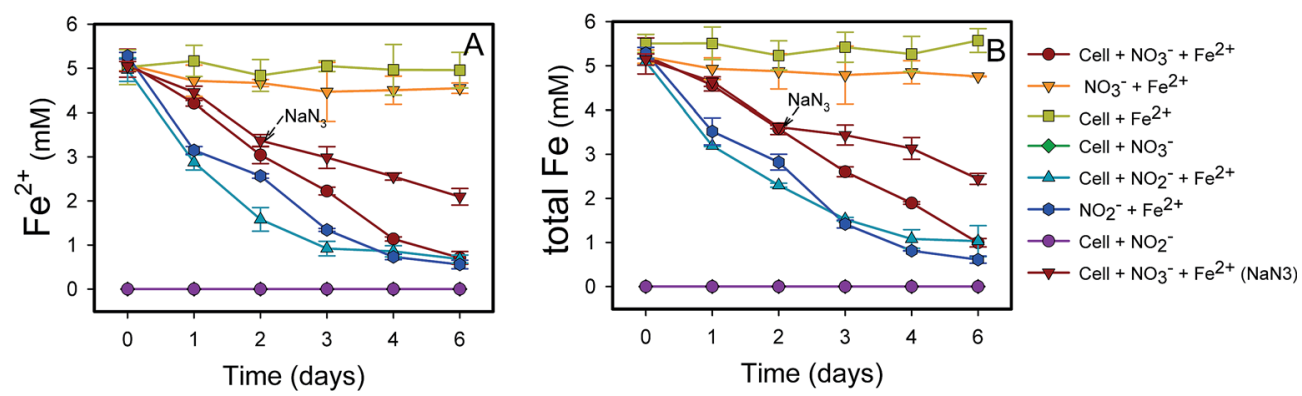

Fig. 2 Transformations of dissolved Fe(॥) (A) and total Fe (B) by (1) Rhodocyclaceae sp. strain Paddy-1 ( $10^{9}$ cells per $\left.\mathrm{ml}\right)$ with $10 \mathrm{mM} \mathrm{NO}{ }^{-}$and $5 \mathrm{mM} \mathrm{FeCl}_{2}$; (2) $10 \mathrm{mM} \mathrm{NO}_{3}^{-}$and $5 \mathrm{mM} \mathrm{FeCl}_{2}$; (3) cells with $5 \mathrm{mM} \mathrm{FeCl}_{2}$; (4) cells with $10 \mathrm{mM} \mathrm{NO}_{3}^{--}$; (5) cells with $1 \mathrm{mM} \mathrm{NO}_{2}^{-}$and $5 \mathrm{mM} \mathrm{FeCl}_{2}$; (6) $5 \mathrm{mM} \mathrm{NO}_{2}^{-}$and $5 \mathrm{mM} \mathrm{FeCl}_{2}$; (7) cells with $5 \mathrm{mM} \mathrm{NO}_{2}^{-}$; (8) $20 \mathrm{mM} \mathrm{NaN}_{3}$ was added at the mid-late log phase of growth (2 days) during the NRCFO experiments. In each treatment, $5 \mathrm{mM}$ acetate was added as a carbon substrate. Data were all presented as means \pm standard deviations (SD) of triplicate. When not shown, error bars are smaller than the symbol size.

accumulation was clearly lower in the presence of cells along with $\mathrm{Fe}(\mathrm{II})$ and $\mathrm{NO}_{3}{ }^{-}$than that observed in a control experiment with cells and $\mathrm{NO}_{3}{ }^{-}$only $\left(\mathrm{N}_{2} \mathrm{O} 0.02-0.34 \mathrm{mM}, \mathrm{NH}_{4}{ }^{+} 0.03-0.55\right.$ $\mathrm{mM}$ ) (Fig. 1D). In addition, Fe(II) addition appeared to slightly inhibit the reduction of $\mathrm{NO}_{3}{ }^{-}$. Acetate $(5 \mathrm{mM})$ was completely oxidized by strain Paddy- 1 in the presence of $10 \mathrm{mM} \mathrm{NO}_{3}{ }^{-}$and $5 \mathrm{mM} \mathrm{Fe}(\mathrm{II})$ after incubation for 4 days (Fig. 3). Adding $\mathrm{NaN}_{3}$ inhibited acetate oxidation during NRCFO (Fig. 3). Moreover, the consumption of acetate was much lower under NRCFO than under biotic $\mathrm{NO}_{3}{ }^{-}$-reducing conditions alone, indicating that the contribution of acetate as an electron donor was diminished and that the electron transferred to $\mathrm{NO}_{3}{ }^{-}$was partly derived from $\mathrm{Fe}(\mathrm{II})$ under NRCFO conditions.

Most $\mathrm{NO}_{3}{ }^{-}$-reducing $\mathrm{Fe}(\mathrm{II})$ oxidizers isolated to date require organic substrates for growth. ${ }^{15,17,26,36}$ In addition to acetate, alternative carbon sources such as formate, glucose, sucrose, glycerol, alcohol, and citrate may be utilized by strain Paddy- 1 under anoxic conditions (Fig. S3†). However, lactate cannot be used by this strain, suggesting that it is a mixotrophic

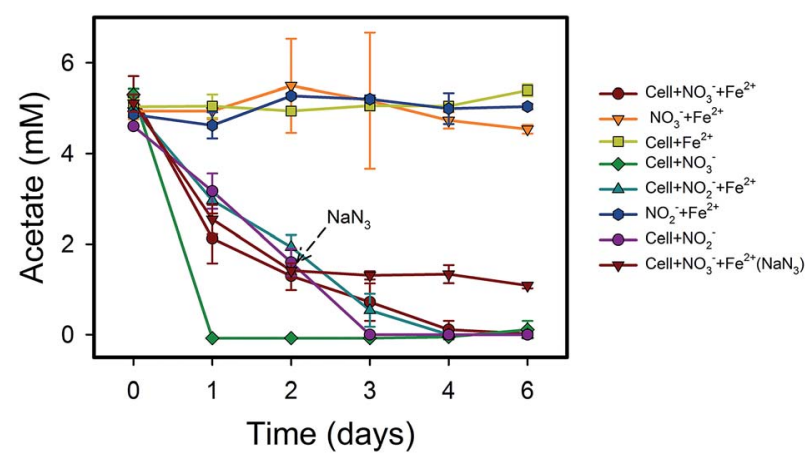

Fig. 3 The oxidation of acetate by (1) Rhodocyclaceae sp. strain Paddy-1 ( $\sim 10^{9}$ cells per $\mathrm{ml}$ ) with $10 \mathrm{mM} \mathrm{NO}_{3}{ }^{-}$and $5 \mathrm{mM} \mathrm{FeCl}_{2}$; (2) $10 \mathrm{mM} \mathrm{NO}_{3}{ }^{-}$ and $5 \mathrm{mM} \mathrm{FeCl}_{2}$; (3) cells with $5 \mathrm{mM} \mathrm{FeCl}_{2}$; (4) cells with $10 \mathrm{mM} \mathrm{NO}_{3}^{-}$; (5) cells with $1 \mathrm{mM} \mathrm{NO}_{2}{ }^{-}$and $5 \mathrm{mM} \mathrm{FeCl}_{2}$; (6) $5 \mathrm{mM} \mathrm{NO}_{2}{ }^{-}$and $5 \mathrm{mM} \mathrm{FeCl}_{2}$; (7) cells with $5 \mathrm{mM} \mathrm{NO}_{2}^{-}$; (8) $20 \mathrm{mM} \mathrm{NaN}_{3}$ was added at the mid-late log phase of growth (2 days) during the NRCFO experiments. In each treatment, $5 \mathrm{mM}$ acetate was added as a carbon substrate. Data were all presented as means \pm standard deviations (SD) of triplicate. When not shown, error bars are smaller than the symbol size. bacterium that can utilize inorganic Fe(II) or organic acid as an electron donor. The respiratory pathways of various carbon sources (included lactate, formate, glucose, sucrose, glycerol, alcohol and citrate) in strain Paddy-1 may produce different amount of energy and impact the cellular activities, resulting in the rate variation of $\mathrm{Fe}(\mathrm{II})$ oxidation.

\section{3 $\mathrm{Fe}(\mathrm{III})$ oxyhydroxide formation and characterization}

The mineralogical characteristics of biogenic iron oxidation products of strain Paddy- 1 were examined by XRD and SEMEDS. The broad background peaks present in the XRD spectrum suggested that poorly crystalline $\mathrm{Fe}(\mathrm{III})$ oxides were produced by strain Paddy-1 (Fig. S4 $\uparrow$ ), consistent with the XRD analysis of $\mathrm{Fe}(\mathrm{III})$ precipitates generated by other NRCFO species. ${ }^{16,37}$ Amorphous iron oxides were observed on the cell surface of strain Paddy-1 and no crystalline iron oxides were detected by SEM (Fig. 4A). SEM analysis also revealed aggregates of cells that were encrusted with oxide precipitates after 20 days of incubation in the presence of $\mathrm{Fe}(\mathrm{II})$ plus acetate and $\mathrm{NO}_{3}{ }^{-}$. High peaks of iron and oxygen were observed in the SEM-EDS images (Fig. 4A), indicating that ferric iron oxyhydroxides are the main oxidation products.

\subsection{Genome properties of strain Paddy- 1 and metabolic pathways compared to other $\mathrm{NO}_{3}{ }^{-}$-reducing $\mathrm{Fe}(\mathrm{II})$-oxidizing species}

The draft genome of Paddy-1 was 3554565 bp in length, which was similar to those of other anaerobic NRCFO species such as Acidovorax sp. BoFeN1 (4.0 Mbp), A. ebreus TPSY (3.8 Mbp), A. delafieldii 2AN (3.8 Mbp), and Pseudogulbenkiania sp. 2002 (4.2 Mbp) (Fig. 5). The genome was found to encode 3153 proteinencoding genes, three ribosomal operons, and 50 tRNA genes.

The average GC content of seven $\mathrm{NO}_{3}{ }^{-}$-reducing $\mathrm{Fe}(\mathrm{II})$ oxidizer genomes ranged from $63.8-64.8 \%$. The evolutionary relatedness of $\mathrm{NO}_{3}{ }^{-}$-reducing $\mathrm{Fe}(\mathrm{II})$ oxidizers was examined by calculating the ANI among genomes. The phylogenetic tree based on pairwise comparison of ANI values confirmed the relatedness of strain Paddy- 1 to the other $\mathrm{NO}_{3}{ }^{-}$-reducing $\mathrm{Fe}(\mathrm{II})$ oxidizers (Fig. 5), and is consistent with previously determined phylogenies based on 16S rRNA gene sequences (Fig. S2 $†$ ). ANI 


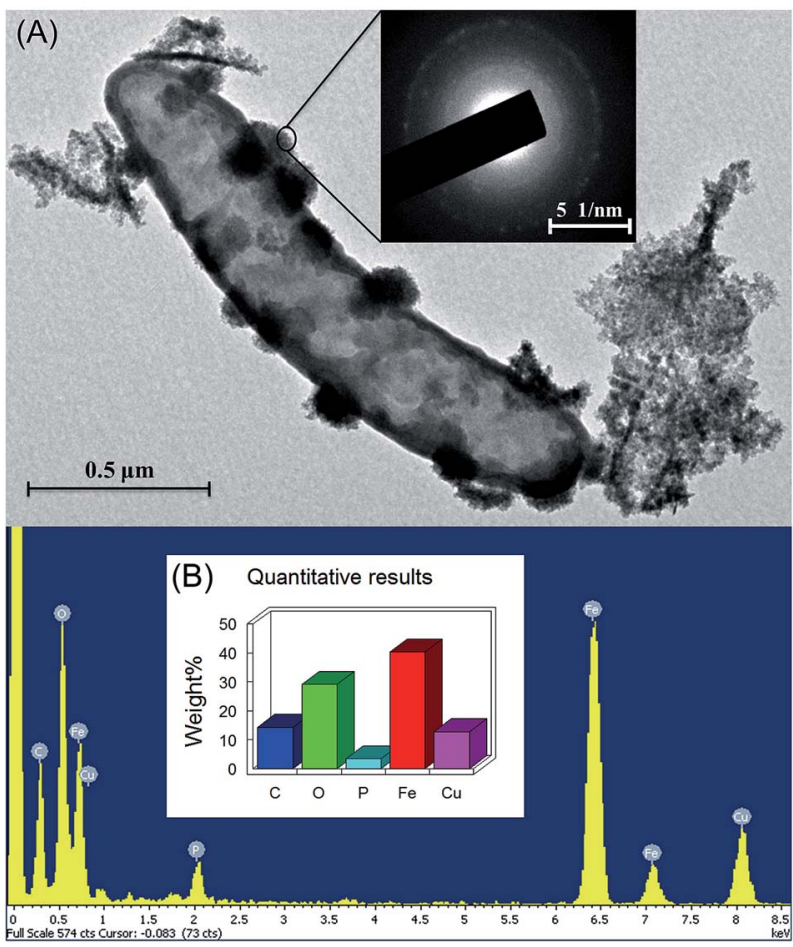

Fig. 4 Scanning electron microscope (SEM) photographs and transmission electron micrographs (TEM) and energy dispersive X-ray spectrometry (EDS) of solids present in the suspension of Rhodocyclaceae sp. strain Paddy-1 in the presence of $10 \mathrm{mM}$ nitrate, $5 \mathrm{mM}$ $\mathrm{FeCl}_{2}$ and $5 \mathrm{mM}$ acetate at day 24 of incubation time. (A) Topography of a single cell with uniform Fe(III) oxyhydroxide encrustations after $12 \mathrm{~h}$ of incubation; (B) EDS analysis of Rhodocyclaceae sp. strain Paddy-1. Vertical line indicates the characteristic peak position of the element. Peak area represents the content of the element.

values among known $\mathrm{NO}_{3}{ }^{-}$-reducing $\mathrm{Fe}(\mathrm{II})$ oxidizers ranged from $67.2-84.1 \%$ (Fig. S5†). The genome of strain Paddy-1 was most similar to that of A. suillum PS, with an ANI of 76.3, and had ANI values ranging from $78.2 \%$ to $84.4 \%$ with respect to other $\mathrm{NO}_{3}{ }^{-}$-reducing $\mathrm{Fe}(\mathrm{II})$ oxidizers in the genus Acidovorax (Acidovorax sp. BeFeN1, A. delafieldii 2AN, and A. ebreus TPSY) (Fig. 5 and S5†).

To compare the metabolic pathways of $\mathrm{NO}_{3}{ }^{-}$-reducing $\mathrm{Fe}(\mathrm{II})-$ oxidizing species, open reading frames (ORFs) were annotated based on Blastx analyses against the eggNOG and KEGG databases. The number of predicted ORFs in these species ranges from 2770 to 4061 with an average of 3943 , corresponding to a coding density in the draft genome of $87.2 \% \pm 4.1 \%$ (average $\pm \mathrm{SD}$ ) (Fig. 5). On average, $80.6 \%$ (range: $61.3-90.5 \%$ ) and $47.5 \%$ (range: $38.1-9.5 \%$ ) of ORFs were annotated in the eggNOG and KEGG databases. The results showed that the functional composition of genes was similar across genomes, with function unknown (simplified as [S] , average \pm SD: $27.2 \%$ $\pm 1.3 \%$ ), amino acid metabolism and transport ([E], 7.0\% \pm $1.4 \%)$, energy production and conversion ([C], $6.8 \% \pm 0.2 \%$ ), inorganic ion transport and metabolism ([P], $6.6 \% \pm 0.6 \%$ ), signal transduction ([T], $6.4 \% \pm 1.7 \%)$, and cell wall/ membrane/envelop biogenesis ([M], $5.5 \% \pm 0.9 \%$ ) as the dominant orthologous groups in the eggNOG categories (Fig. S6 $\dagger$ ). There was greater divergence in the functional composition of KEGG as compared to eggNOG categories among genomes, with functions associated with amino acid metabolism (average \pm SD: $12.0 \% \pm 1.1 \%$ ) being the most abundant, followed by carbohydrate metabolism $(10.1 \% \pm$ $0.4 \%)$ and energy metabolism $(10.0 \% \pm 0.6 \%)$ (Fig. S7†). Most detected functions were common to all genomes, suggesting similarities in the metabolic capabilities of different $\mathrm{NO}_{3}{ }^{-}-$ reducing $\mathrm{Fe}$ (II) oxidizers. In particular, eggNOG and KEGG functional clustering showed more similarity between the genomes of strain Paddy- 1 and A. suillum PS (Fig. S8 and S9†), whereas the other $\mathrm{NO}_{3}{ }^{-}$-reducing $\mathrm{Fe}(\mathrm{II})$-oxidizing species (Acidovorax sp. BeFeN1, A. delafieldii 2AN, and A. ebreus TPSY) belonging to genus Acidovorax were grouped together. These patterns were similar to the results obtained in the phylogenetic
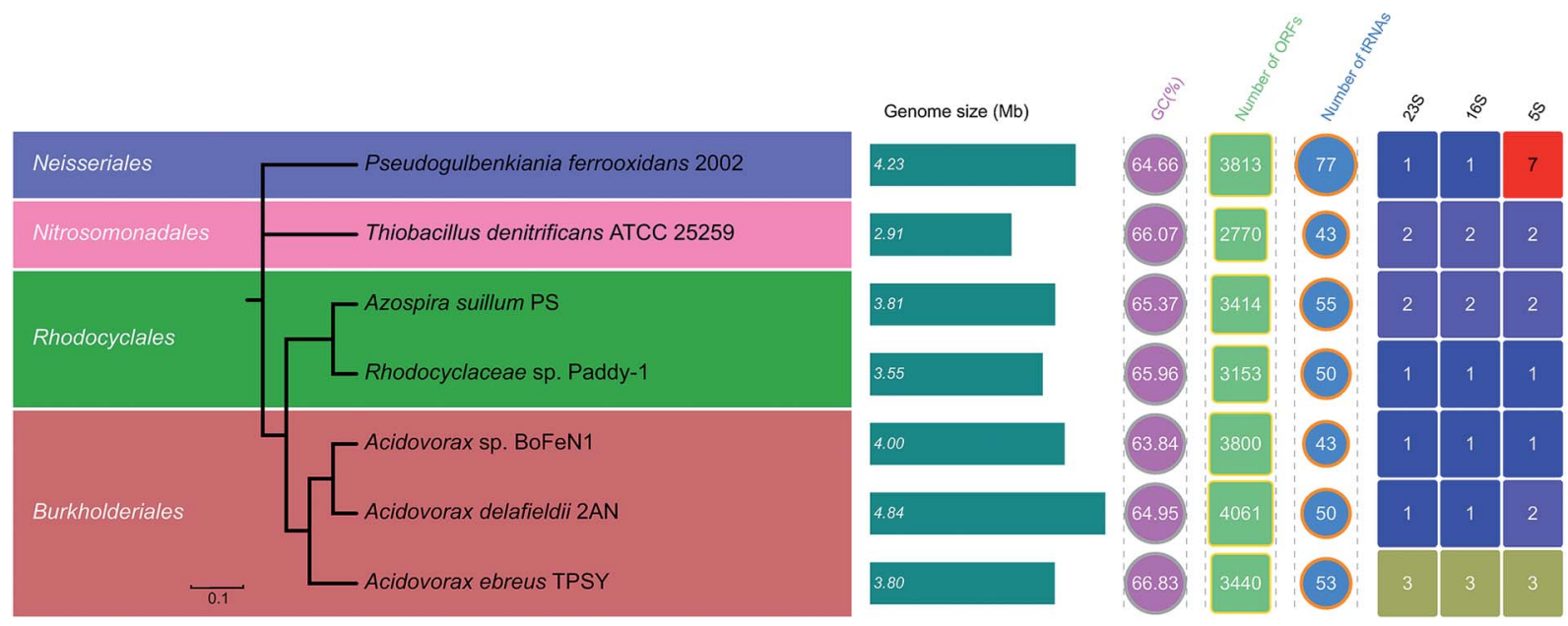

Fig. 5 Average nucleotide identity (ANI)-based neighbor-joining tree and genome features of seven sequenced strains capable of nitrate reduction coupled $\mathrm{Fe}($ II) oxidation. The evolutionary relatedness was examined by calculation of ANI, based on draft or complete genome sequences. Scale indicates the \% difference ANI. 
analysis based on 16S rRNA genes (Fig. S2 $\dagger$ ) or ANI values (Fig. 5).

Denitrification-related genes. During incubation of strain Paddy-1, the concentration of generated $\mathrm{NO}_{2}{ }^{-}$remained at low levels $\left(1.57 \mathrm{mM}\right.$, Fig. 1B), suggesting that $\mathrm{NO}_{2}{ }^{-}$is further converted to $\mathrm{N}_{2} \mathrm{O}, \mathrm{N}_{2}$, or $\mathrm{NH}_{4}{ }^{+}$. Genes encoding all of the components of the denitrification pathway were present in the genome of strain Paddy-1, including $\mathrm{NO}_{3}{ }^{-}$reductase $(\operatorname{nar} G), \mathrm{NO}_{2}{ }^{-}$ reductase (nirK), nitric oxide reductase (nor $B$ ), nitrous oxide reductases (nosZ), and ferredoxin- $\mathrm{NO}_{2}{ }^{-}$reductase (nirA) (Fig. 6). These results are consistent with the change in nitrogen speciation during the process of $\mathrm{NO}_{3}{ }^{-}$-reducing anaerobic oxidation of ferrous iron by strain Paddy- 1 with acetate as substrate.

Iron homeostasis machinery. Unexpectedly, strain Paddy-1 has a large number of iron homeostasis related components, including 41 putative genes encoding (poly)ferredoxin, flavodoxins, bacterioferritin, (proto)heme, and siderophore (Table $\mathrm{S} 3 \dagger)$. These components could ensure iron acquisition and consumption by cells in vivo. In addition, iron storage proteins such as ferritin were also present, and could provide intracellular iron reserves when the external supply is restricted. Strain Paddy-1 had nine ORF-encoding Feo $B$ transporters that facilitate $\mathrm{Fe}(\mathrm{II})$ import into the periplasm; extracellular ferric chelators such as siderophores were also detected. The strain Paddy-1 genome also harbored membrane-integral $\mathrm{Fe}(\mathrm{II})$ permease (COG0672, ORF_0429) and ferric reductase (COG4097, ORF_2503, and ORF_1211), which participate in Fe(II) transmembrane transport and Fe(III) reduction, respectively (Table S3†).

Putative genes encoding cytochrome c, iron oxidase, and electron transport chain components for $\mathrm{Fe}$ (II) oxidation. Automated annotation of the genome of strain Paddy-1 predicted 31 genes encoding c-type cytochromes or related proteins, two of which were highly homologous to di-heme ctype cytochromes (Table S2 $\dagger$ ). In addition to these genes, we identified 29 genes encoding or related to cytochrome $c$ (including cytochrome $c 1, c 2, c 5, c 553$, and $c 556$ ), which plays an important role in electron transfer and exhibits high iron ionbinding capacity. Bioinformatics analyses have enabled the identification of putative electron transport chain components involved in Fe(II) oxidation. ${ }^{38,39}$ Manual curation of the Paddy-1 genome revealed a number of high-similarity homologs of iron oxidase or electron transfer proteins in the acidophilic, $\mathrm{Fe}(\mathrm{II})$ oxidizer A. ferrooxidans 23270 and the dissimilatory $\mathrm{Fe}(\mathrm{III})$ reducer $S$. oneidensis MR-1 (Table S4†). A cyc2 homolog ( $E$ value $=3 \times 10^{-33}$ ) was found in the strain Paddy-1 genome. Cyc2 gene encodes a cytochrome located in the outer membrane of the cell that catalyzes the oxidation of $\mathrm{Fe}(\mathrm{II})$ to $\mathrm{Fe}(\mathrm{III})$. Furthermore, homologs of electron transfer complex proteins including cyc1 $\left(E\right.$ value $\left.=9.00 \times 10^{-32}\right), \operatorname{cyc} A-2\left(E\right.$ value $\left.=2.00 \times 10^{-11}\right)$, and cyc $A-1\left(E\right.$ value $\left.=1.00 \times 10^{-28}\right)$ were also predicted based on the genomic information. In addition, the homologs of $\mathrm{Feo} B$ (a ferrous iron transport protein) and $\operatorname{cym} A$ (a hydroquinone dehydrogenase) in $S$. oneidensis MR-1 had $E$ values of $8.00 \times$ $10^{-8}$ and $1.00 \times 10^{-31}$, respectively. ${ }^{40,41}$ In $S$. oneidensis, cym $A$ is a tetraheme c-type cytochrome that is presumed to localize to the cytoplasmic membrane where it mediates electron transfer from the quinone/quinol pool. ${ }^{41}$ We propose that the proteins encoded by these genes are key components of the Fe-oxidizing pathway in strain Paddy-1 (Table S3†).

\section{Discussion}

\subsection{Beneficial effects of poorly crystalline $\mathrm{Fe}$ (III) minerals produced by NRCFO species}

The microbial $\mathrm{Fe}(\mathrm{II})-\mathrm{Fe}$ (III) cycle promotes various environmental processes at the water-soil interface, including nutrient cycling and contaminant transformation. ${ }^{42,43} \mathrm{Fe}(\mathrm{II})$ produced by dissimilatory $\mathrm{Fe}(\mathrm{III})$-reducing bacteria can be re-oxidized to Fe(III) via a chemical or biological process to complete the iron cycle. Crystalline Fe(III) minerals produced at lower levels by NRCFO species were shown to act as excellent electron acceptors for dissimilatory $\mathrm{Fe}(\mathrm{III})$-reducing bacteria. ${ }^{44,45} \mathrm{Fe}(\mathrm{III})$ mineral phases of NRCFO products are often poorly crystalline and their mineralogy is determined by factors such as medium composition, $\mathrm{pH}$, co-substrate concentrations, incubation conditions, Fe(II) oxidation rates, and presence of humic compounds or other ligands. ${ }^{16,46}$ In this study, strain Paddy-1 oxidized Fe(II) mixotrophically in the presence of acetate and $\mathrm{NO}_{3}{ }^{-}$, forming

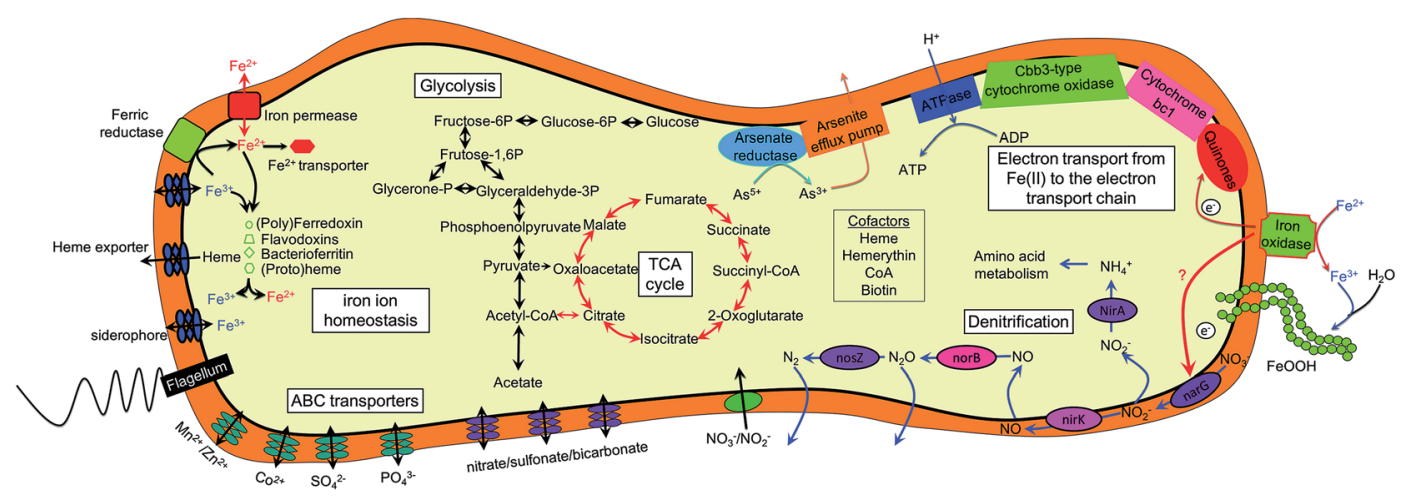

Fig. 6 Cell metabolic cartoon based on the annotation of Rhodocyclaceae sp. strain Paddy-1 genome. Possible mechanisms for energetic benefit from nitrate reduction coupled to Fe(I) oxidation in the cell of Rhodocyclaceae sp. strain Paddy-1 was shown. narG, nitrate reductase; nirK, nitrite reductase; nor $B$, nitric oxide reductase; nos $Z$, nitrous oxide reductase; nir $A$, ferredoxin-nitrite reductase. 
$\mathrm{Fe}(\mathrm{III})$ mineral crusts around the cell (Fig. 4). The production of poorly crystalline Fe(III) oxides by Paddy-1 was confirmed by $\mathrm{XRD}$ (Fig. S4 $\mathrm{S}^{\dagger}$ ) and is consistent with observations in other NRCFO species. ${ }^{37,47-49}$ These poorly soluble Fe(III) oxides prevent encrustation of metabolizing cells, which can impair substrate uptake and metabolite release and may lead to cell death. ${ }^{\mathbf{5 0}}$ Furthermore, the low levels of crystalline Fe(III) produced by NRCFO bacteria may act as nucleation sites to promote the growth of iron oxides with a higher-order crystalline structure, ${ }^{16,51}$ and may be transformed into hematite $\left(\mathrm{Fe}_{2} \mathrm{O}_{3}\right)^{52}$ or decomposed to lower-order species that are transformed into highly crystalline forms such as goethite. ${ }^{53}$ In addition to releasing dissolved $\mathrm{Fe}(\mathrm{II}), \mathrm{Fe}(\mathrm{III})$-reducing bacteria could also catalyze the transformation of poorly ordered $\mathrm{Fe}$ (III) hydroxides into higher crystalline $\mathrm{Fe}(\mathrm{III})$ minerals via a dissolution/reprecipitation mechanism ${ }^{39}$ that yields secondary iron minerals such as ferrihydrite, goethite, magnetite, or even carbonated green rust. ${ }^{54,55}$ In addition to enhancing iron cycling, poorly crystalline $\mathrm{Fe}$ (III) minerals produced by NRCFO species can potentially attenuate environmental contaminants present in rice paddy soils. Less crystalline $\mathrm{Fe}(\mathrm{III})$ minerals are more readily utilized by dissimilatory $\mathrm{Fe}$ (III)-reducing microorganisms, which can use organic pollutants such as aromatic hydrocarbons as electron donors. ${ }^{56}$ They also have a larger surface area that increases their capacity for binding toxic metals such as arsenic and cadmium. ${ }^{57}$

\subsection{Abiotic reactions in microbe-mediated NRCFO}

Discerning whether biotic or abiotic processes control $\mathrm{Fe}$ (II) oxidation remains a major challenge. ${ }^{1} \mathrm{Fe}(\mathrm{II})$ can be abiotically oxidized by $\mathrm{Mn}(\mathrm{III}) / \mathrm{Mn}$ (Iv) oxide, copper, and green rust. $^{26,54,55,58,59}$ The indirect abiotic process of $\mathrm{Fe}(\mathrm{II})$ oxidation may be driven by heterotrophic $\mathrm{NO}_{3}{ }^{-}$-reducing bacteria via reactive nitrogen $(\mathrm{N})$ species $\left(\mathrm{NO}_{2}{ }^{-}\right.$, NO) generated by denitrification. ${ }^{54}$ Analysis of nitrogen species in strain Paddy-1 cultures with $\mathrm{FeCl}_{2}$ and $\mathrm{NO}_{3}{ }^{-}$showed that the $\mathrm{NO}_{2}{ }^{-}$concentration was $<1 \mathrm{mM}$ after 3 days when $\mathrm{Fe}(\mathrm{II})$ was rapidly oxidized (Fig. 1 and 2). $\mathrm{NO}_{2}{ }^{-}$accumulation $(\sim 0.5-1.5 \mathrm{mM})$ in cultures has been reported in other NRCFO studies. ${ }^{14,16,60}$ The kinetics of $\mathrm{Fe}(\mathrm{II})$ oxidation by $\mathrm{NO}_{2}{ }^{-}$are generally more rapid under anoxic conditions, ${ }^{\mathbf{6 1 , 6 2}}$ with the slowest reaction rate observed at neutral $\mathrm{pH}$. In this study, $20 \mathrm{mM} \mathrm{NaN}_{3}$ was added at the midlate log growth phase in the NRCFO experiments as a control to confirm that active cells must be present for $\mathrm{Fe}(\mathrm{II})$ oxidation. $\mathrm{NaN}_{3}$ can inhibit cell growth and metabolic activity. ${ }^{63} \mathrm{Fe}(\mathrm{II})$ oxidation and $\mathrm{NO}_{3}{ }^{-}$reduction rates were reduced by $\mathrm{NaN}_{3}$ relative to their no- $\mathrm{NaN}_{3}$ NRCFO counterparts, implying that NRCFO is mediated by active cells (Fig. 1 and 2). The slower consumption of acetate under NRCFO as compared to biotic $\mathrm{NO}_{3}{ }^{-}$-reducing conditions (Fig. 3) indicated that the contribution of acetate as an electron donor was reduced and that the electron transferred to $\mathrm{NO}_{3}{ }^{-}$was partly derived from $\mathrm{Fe}$ (II) through NRCFO.

The kinetics and reaction pathways of Fe(II) oxidation by $\mathrm{NO}_{2}{ }^{-}$are strongly affected by medium composition, $\mathrm{pH}$, reactant concentration, and the presence of $\mathrm{Fe}(\mathrm{II})$-sorptive (e.g.,
Fe(III) oxyhydroxides) and cell surfaces. ${ }^{64} \mathrm{Fe}^{2+}$ adsorbed on crystalline $\mathrm{Fe}(\mathrm{III})$ oxyhydroxides is a stronger reactant for $\mathrm{NO}_{2}{ }^{-}$ than dissolved $\mathrm{Fe}^{2+} \cdot{ }^{65}$ It is possible that the abiotic reaction between $\mathrm{NO}_{2}{ }^{-}$and $\mathrm{Fe}^{2+}$ absorbed on crystalline $\mathrm{Fe}(\mathrm{III})$ oxyhydroxides increase the risk of overestimating the microbial contribution to NRCFO. However, Fe(III) oxyhydroxides produced by strain Paddy-1 were poorly crystalline in form, which reduced the possibility that adsorbed $\mathrm{Fe}(\mathrm{II})$ would react with generated $\mathrm{NO}_{2}{ }^{-}$. Because adsorbed $\mathrm{Fe}(\mathrm{II})$ is difficult to distinguish on the surface of cells or Fe(III) oxyhydroxides, it is not possible to evaluated its effect on $\mathrm{NO}_{2}{ }^{-}$reduction in a biotic system. Continuous flow systems can limit the absorption of $\mathrm{Fe}(\mathrm{II})$ absorbed to the cell or Fe(III) oxyhydroxide surface, thereby minimizing the abiotic reaction between $\mathrm{Fe}(\mathrm{II})$ and $\mathrm{NO}_{2}{ }^{-}{ }^{\mathbf{1 4}}$ Additionally, factors such as substrate concentration and buffer type should be carefully considered in NRCFO studies. Until recently, $\mathrm{Fe}(\mathrm{II})$ and $\mathrm{NO}_{3}{ }^{-}$concentrations used in these studies were in the $\mathrm{mM}$ range, which is much higher than those found in the natural environment. A culture system with low concentrations of substrate ( $\mathrm{Fe}(\mathrm{II}), \mathrm{NO}_{3}{ }^{-}$, and acetate) could prevent encrustation by generated $\mathrm{Fe}(\mathrm{III})$ oxides and reduce their effects on cellular activity. ${ }^{\mathbf{1 4}}$ Iron isotopes have been successfully applied in the study of $\mathrm{NO}_{3}{ }^{-}$-reducing and photoautotrophic $\mathrm{Fe}(\mathrm{II})$-oxidizing bacteria. ${ }^{\mathbf{6 6 , 6 7}}$ The distinct iron isotope fractions generated by chemical and biological Fe(II) oxidation could serve as indicators of chemical and biological Fe(II) oxidation in the NRCFO process. Therefore, additional studies are warranted using continuous flow systems combined with iron isotope fractionation under much lower $\mathrm{Fe}(\mathrm{II})$ and $\mathrm{NO}_{3}{ }^{-}$concentrations to characterize NRCFO by strain Paddy- 1 .

\section{3 $\mathrm{Fe}(\mathrm{II})$-oxidizing pathway predicted from the genomic analysis}

Although NRCFO has been reported in many species under various conditions, our understanding of the $\mathrm{Fe}(\mathrm{II})$ oxidation pathway in this process remains limited. For instance, the location of $\mathrm{Fe}(\mathrm{II})$ oxidase in these cells has not been determined. ${ }^{3}$ This raises the question of whether Fe(II) is taken up by cells and oxidized in the periplasm or cytoplasm, or whether electrons are transferred from $\mathrm{Fe}(\mathrm{II})$ to the outer cell membrane. The cellular and biochemical evidence for the existence of enzymatic $\mathrm{NO}_{3}{ }^{-}$-reducing $\mathrm{Fe}(\mathrm{II})$ oxidation is inconclusive due to the lack of an efficient gene knockout system in these microorganisms. Genome sequencing of several NRCFO species such as A. ebreus TPSY, ${ }^{15} T$. denitrificans ATCC $25259,{ }^{38}$ and Pseudogulbenkiania sp. 2002 (ref. 68) has provided insight into the potential biochemical and genetic mechanisms of NDFO. Initial oxidation of $\mathrm{Fe}$ (II) to $\mathrm{Fe}$ (III) is performed by $\mathrm{Fe}$ (II) oxidase present on the cell surface or in the outer membrane in acidophilic and photosynthetic $\mathrm{Fe}(\mathrm{II})$ oxidizers, ${ }^{69,70}$ which can prevent $\mathrm{Fe}(\mathrm{III})$ mineral precipitation within the cell. Comparative genomics have revealed $\mathrm{Fe}(\mathrm{II})$ oxidation factors in microaerophilic species ${ }^{39,71}$ including Cyc2 in acidophilic A. ferrooxidans, ${ }^{72} \mathrm{PioA} /$ $B$ in photoferrotrophic $R$. palustris TIE- $1,{ }^{70}$ Fox $E$ in Rhodobacter sp. SW2, ${ }^{73}$ and Mto $A$ in microaerobic $S$. lithotrophicus ES-1. ${ }^{39}$ However, iron oxidases in NRCFO species remain poorly 
understood..$^{12}$ In this study, we found that the genome of strain Paddy-1 encodes a homolog of A. ferrooxidans Cyc2-which is located on the outer cell membrane and directly catalyzes $\mathrm{Fe}$ (II) oxidation $^{72}$-along with homologs of component of the electron-conducting super-complex spanning the outer and inner membranes of the cytoplasm (cyc1, cyc $A 1$ and cyc $A 2$ in $A$. ferrooxidans) (Table $\mathrm{S} 4 \dagger$ ). Enzymatic assays to determine the localization of the Fe(II) oxidase activity of NRCFO species is necessary in order to elucidate the molecular mechanism of NRCFO in microorganisms. In addition, newly developed proteomics tools such as isobaric tags for relative and absolute quantitation-labeling protein quantification ${ }^{74}$ and sequential windowed acquisition of all theoretical fragment ion mass spectra $^{75}$ are useful for identifying proteins that participate in electron transfer in the NRCFO process and clarifying the role of c-type cytochromes in $\mathrm{Fe}(\mathrm{II})$ oxidation.

\section{Conclusions}

Anaerobic NRCFO has been observed in anoxic freshwater and sediment environments. However, in situ NRCFO in paddy soil-the most widely distributed and constructed wetland system worldwide-has not been previously reported. In this study, we isolated the NRCFO strain Paddy-1 from paddy soil located in iron-rich Southern China and performed wholegenome sequencing to identify some of its critical metabolic components. Additional studies are necessary to determine whether abiotic or biotic reactions are more abundant in the microbe-mediated NRCFO process; moreover, proteins that directly catalyze $\mathrm{Fe}(\mathrm{II})$ oxidation in NRCFO species warrant more detailed investigation by proteomics and high-throughput genetic analyses using a systems biology approach.

\section{Conflicts of interest}

There are no conflicts to declare.

\section{Acknowledgements}

This work was supported by the NSFC-Guangdong Joint Fund (U1401234), National Science Foundation of China (No. 41330857, 41201253), the National Key Technology R\&G Program of China (2015BAD05B05), Guangdong Key Technologies R\&D Program (2015B020207001) and Natural Science Foundation of Guangdong Province (2017A030313218). We thank Tiffany Louie for thoughtful reviews of the manuscript and discussion of the topics therein.

\section{References}

1 E. D. Melton, E. D. Swanner, S. Behrens, C. Schmidt and A. Kappler, Nat. Rev. Microbiol., 2014, 12, 797-808.

2 L. J. Ding, X. L. An, S. Li, G. L. Zhang and Y. G. Zhu, Environ. Sci. Technol., 2014, 48, 10641-10647.

3 N. Klueglein and A. Kappler, Geobiology, 2013, 11, 180-190.
4 K. J. Edwards, D. R. Rogers, C. O. Wirsen and T. M. McCollom, Appl. Environ. Microbiol., 2003, 69, 29062913.

5 D. Emerson and C. L. Moyer, Appl. Environ. Microbiol., 2002, 68, 3085-3093.

6 R. E. James and F. G. Ferris, Chem. Geol., 2004, 212, 301-311.

7 D. Kanaparthi, B. Pommerenke, P. Casper and M. G. Dumont, ISME J., 2013, 7, 1582-1594.

8 D. Sobolev and E. E. Roden, Geomicrobiol. J., 2004, 21, 1-10.

9 K. Laufer, H. Røy, B. B. Jørgensen and A. Kappler, Appl. Environ. Microbiol., 2016, 82, 6120-6131.

10 S. Ratering and S. Schnell, Environ. Microbiol., 2001, 3, 100109.

11 K. R. Reddy, W. H. Patrick and F. E. Broadbent, Crit. Rev. Environ. Sci. Technol., 1984, 13, 273-309.

12 M. Ilbert and V. Bonnefoy, Biochim. Biophys. Acta, Bioenerg., 2013, 1827, 161-175.

13 C. Achtnich, F. Bak and R. Conrad, Biol. Fertil. Soils, 1995, 19, 65-72.

14 A. Chakraborty, E. E. Roden, J. Schieber and F. Picardal, Appl. Environ. Microbiol., 2011, 77, 8548-8556.

15 K. G. Byrne-Bailey, K. A. Weber, A. H. Chair, S. Bose, T. Knox, T. L. Spanbauer, O. Chertkov and J. D. Coates, J. Bacteriol., 2010, 192, 1475-1476.

16 A. Kappler, B. Schink and D. K. Newman, Geobiology, 2005, 3, 235-245.

17 J. G. Lack, S. K. Chaudhuri, R. Chakraborty, L. A. Achenbach and J. D. Coates, Microb. Ecol., 2002, 43, 424-431.

18 K. A. Weber, J. Pollock, K. A. Cole, S. M. O'Connor, L. A. Achenbach and J. D. Coates, Appl. Environ. Microbiol., 2006, 72, 686-694.

19 X. M. Li, W. Zhang, T. X. Liu, L. X. Chen, P. C. Chen and F. B. Li, Soil Biol. Biochem., 2016, 94, 70-79.

20 M. F. Polz and C. M. Cavanaugh, Appl. Environ. Microbiol., 1998, 64, 3724-3730.

21 T. A. Hall, Nucleic Acids Symp. Ser., 1999, 41, 95-98.

22 J. R. Cole, B. Chai, T. L. Marsh, R. J. Farris, Q. Wang, S. A. Kulam, S. Chandra, D. M. McGarrell, T. M. Schmidt, G. M. Garrity and J. M. Tiedje, Nucleic Acids Res., 2003, 31, 442-443.

23 K. Tamura, J. Dudley, M. Nei and S. Kumar, Mol. Biol. Evol., 2007, 24, 1596-1599.

24 O. S. Kim, Y. J. Cho, K. Lee, S. H. Yoon, M. Kim, H. Na, S. C. Park, Y. S. Jeon, J. H. Lee, H. Yi, S. Won and J. Chun, Int. J. Syst. Evol. Microbiol., 2012, 62, 716-721.

25 D. Connolly and B. Paull, Anal. Chim. Acta, 2001, 441, 53-62. 26 K. L. Straub, M. Benz, B. Schink and F. Widdel, Appl. Environ. Microbiol., 1996, 62, 1458-1460.

27 N. Kruger, in The Protein Protocols Handbook, ed. J. Walker, Humana Press, 2009, ch. 4, pp. 17-24, DOI: 10.1007/978-159745-198-7_4.

28 D. R. Zerbino and E. Birney, Genome Res., 2008, 18, 821-829.

29 A. L. Delcher, K. A. Bratke, E. C. Powers and S. L. Salzberg, Bioinformatics, 2007, 23, 673-679.

30 T. M. Lowe and S. R. Eddy, Nucleic Acids Res., 1997, 25, 09550964. 
31 E. Pruesse, C. Quast, K. Knittel, B. M. Fuchs, W. Ludwig, J. Peplies and F. O. Glöckner, Nucleic Acids Res., 2007, 35, 7188-7196.

32 M. Richter and R. Rosselló-Móra, Proc. Natl. Acad. Sci. U. S. A., 2009, 106, 19126-19131.

33 D. H. Huson, Bioinformatics, 1998, 14, 68-73.

34 J. Huerta-Cepas, D. Szklarczyk, K. Forslund, H. Cook, D. Heller, M. C. Walter, T. Rattei, D. R. Mende, S. Sunagawa, M. Kuhn, L. J. Jensen, C. von Mering and P. Bork, Nucleic Acids Res., 2016, 44, D286-D293.

35 M. Kanehisa and S. Goto, Nucleic Acids Res., 2000, 28, 27-30.

36 M. Benz, A. Brune and B. Schink, Arch. Microbiol., 1998, 169, 159-165.

37 B. H. Li, C. Y. Tian, D. Y. Zhang and X. L. Pan, Geomicrobiol. J., 2013, 31, 138-144.

38 H. R. Beller, P. Zhou, T. C. Legler, A. Chakicherla, S. Kane, T. E. Letain and P. A. O'Day, Front. Microbiol., 2013, 4, 249. 39 J. Liu, Z. Wang, S. M. Belchik, M. J. Edwards, C. Liu, D. W. Kennedy, E. D. Merkley, M. S. Lipton, J. N. Butt, D. J. Richardson, J. M. Zachara, J. K. Fredrickson, K. M. Rosso and L. Shi, Front. Microbiol., 2012, 3, 37.

40 C. D. Cordova, M. F. Schicklberger, Y. Yu and A. M. Spormann, J. Bacteriol., 2011, 193, 2312-2321.

41 C. R. Myers and J. M. Myers, J. Bacteriol., 1997, 179, 11431152.

42 T. Borch, R. Kretzschmar, A. Kappler, P. V. Cappellen, M. Ginder-Vogel, A. Voegelin and K. Campbell, Environ. Sci. Technol., 2010, 44, 15-23.

43 P. W. Boyd and M. J. Ellwood, Nat. Geosci., 2010, 3, 675-682. 44 A. Kappler and K. L. Straub, Rev. Mineral. Geochem., 2005, 59, 85-108.

45 K. L. Straub and B. E. E. Buchholz-Cleven, Appl. Environ. Microbiol., 1998, 64, 4846-4856.

46 M. Nordhoff, C. Tominski, M. Halama, J. M. Byrne, M. Obst, S. Kleindienst, S. Behrens and A. Kappler, Appl. Environ. Microbiol., 2017, 83, e00752-17.

47 S. Park, D. H. Kim, J. H. Lee and H. G. Hur, FEMS Microbiol. Ecol., 2014, 90, 68-77.

48 K. L. Straub, W. A. Schönhuber, B. E. E. Buchholz-Cleven and B. Schink, Geomicrobiol. J., 2004, 21, 371-378.

49 L. D. Zhao, H. L. Dong, R. Kukkadapu, A. Agrawal, D. Liu, J. Zhang and R. E. Edelmann, Geochim. Cosmochim. Acta, 2013, 119, 231-247.

50 R. Hallberg and F. G. Ferris, Geomicrobiol. J., 2004, 21, 325330.

51 S. Glasauer, P. G. Weidler, S. Langley and T. J. Beveridge, Geochim. Cosmochim. Acta, 2003, 67, 1277-1288.

52 E. Mendelovici, R. Villalba and A. Sagarzazu, Mater. Res. Bull., 1982, 17, 241-249.
53 N. Yee, S. Shaw, L. G. Benning and T. H. Nguyen, Am. Mineral., 2006, 91, 92-96.

54 M. Etique, F. P. A. Jorand, A. Zegeye, B. Grégoire, C. Despas and C. Ruby, Environ. Sci. Technol., 2014, 48, 3742-3751.

55 C. Pantke, M. Obst, K. Benzerara, G. Morin, G. Ona-Nguema, U. Dippon and A. Kappler, Environ. Sci. Technol., 2012, 46, 1439-1446.

56 J. M. Zachara, R. K. Kukkadapu, J. K. Fredrickson, Y. A. Gorby and S. C. Smith, Geomicrobiol. J., 2002, 19, 179-207.

57 E. M. Muehe, L. Scheer, B. Daus and A. Kappler, Environ. Sci. Technol., 2013, 47, 8297-8307.

58 H. C. B. Hansen, C. B. Koch, H. Nancke-Krogh, O. K. Borggaard and J. Sørensen, Environ. Sci. Technol., 1996, 30, 2053-2056.

59 C. J. Ottley, W. Davison and W. M. Edmunds, Geochim. Cosmochim. Acta, 1997, 61, 1819-1828.

60 P. Larese-Casanova, S. B. Haderlein and A. Kappler, Geochim. Cosmochim. Acta, 2010, 74, 3721-3734.

61 D. W. Nelson and J. M. Bremner, Soil Biol. Biochem., 1970, 2, 1-8.

62 J. T. Moraghan and R. J. Buresh, Soil Sci. Soc. Am. J., 1977, 41, 47-50.

63 H. C. Lichstein and M. H. Soule, J. Bacteriol., 1944, 47, 221230.

64 F. Picardal, Front. Microbiol., 2012, 3, 112.

65 Y.-L. Tai and B. A. Dempsey, Water Res., 2009, 43, 546-552.

66 L. R. Croal, C. M. Johnson, B. L. Beard and D. K. Newman, Geochim. Cosmochim. Acta, 2004, 68, 1227-1242.

67 A. Kappler, C. M. Johnson, H. A. Crosby, B. L. Beard and D. K. Newman, Geochim. Cosmochim. Acta, 2010, 74, 28262842.

68 K. G. Byrne-Bailey, K. A. Weber and J. D. Coates, J. Bacteriol., 2012, 194, 2400-2401.

69 V. Bonnefoy and D. S. Holmes, Environ. Microbiol., 2012, 14, 1597-1611.

70 Y. Q. Jiao and D. K. Newman, J. Bacteriol., 2007, 189, 17651773.

71 S. Kato, M. Ohkuma, D. H. Powell, S. T. Krepski, K. Oshima, M. Hattori, N. Shapiro, T. Woyke and C. S. Chan, Front. Microbiol., 2015, 6, 1265.

72 A. Yarzábal, G. Brasseur, J. Ratouchniak, K. Lund, D. Lemesle-Meunier, J. A. DeMoss and V. Bonnefoy, J. Bacteriol., 2002, 184, 313-317.

73 L. R. Croal, Y. Q. Jiao and D. K. Newman, J. Bacteriol., 2007, 189, 1774-1782.

74 K. Aggarwal, L. H. Choe and K. H. Lee, Briefings Funct. Genomics, 2006, 5, 112-120.

75 X. Zhu, Y. Chen and R. Subramanian, Anal. Chem., 2014, 86, 1202-1209. 